\title{
Anti-intermediate filament antibodies, antikeratin antibody, and antiperinuclear factor in rheumatoid arthritis and infectious mononucleosis
}

\author{
P K KATAAHA, S M MORTAZAVI-MILANI, G RUSSELL, AND \\ E J HOLBOROW
}

From the Bone and Joint Research Unit, The London Hospital Medical College, 25-29 Ashfield Street, $\stackrel{\varrho}{\stackrel{\varrho}{\circ}}$ London E1 $2 A D$

SUMMARY Sera from patients with rheumatoid arthritis (RA), patients with infectious mononucleosis (IM), and blood donors were tested by indirect immunofluorescence for the presence of antikeratin antibody (AKA), antibody to cytoskeletal intermediate filaments of prekeratin or vimentin type (AIFA) and antiperinuclear factor (APF). In $81.9 \%$ of the RA sera and $92.5 \%$ of the IM sera AIFA of IgM class was found at titres up to and in some casesop exceeding $1 / 160$. In blood donors the incidence of AIFA was $26 \%$, at titres not exceeding $1 / 20$. AKA and APF, always of IgG class, were found in $54.2 \%$ and $73.6 \%$ of rheumatoid sera. A weako correlation was found in RA between the incidence of AIFA and APF. AKA was not present in either IM or blood donor sera, and APF was found in only $2 \cdot 5 \%$ and $3 \cdot 2 \%$ of IM or blood donors respectively.

Among the non-organ-specific autoantibodies found in the sera of rheumatoid arthritis (RA) patients are three directed at different components in epithelial cells. These are antikeratin antibody (AKA), antibodies against intermediate filaments (AIFA), and antiperinuclear factor (APF). All three are shown by indirect immunofluorescence; AKA by reactivity with keratinised cells in rat oesophageal epithelium, ${ }^{35}$ APF by reactivity with keratohyaline granules in buccal mucosal cells, ${ }^{34}$ and AIFA by cytoskeletal staining in cultured cell monolayers. ${ }^{26}$ AIFA in RA sera may have specificity for the intermediate filament proteins vimentin or prekeratin, or both; specificity for prekeratin is shown by staining of the fine cytoplasmic network of filaments which persist in epithelial cells (usually $\mathrm{HEp}_{2}$ cells) that have been cultured in the presence of colchicine. In such cells or in similarly treated fibroblasts, vimentin is stained as perinuclear coils. We report here the incidence of these three autoantibodies in RA patients, in patients with infectious mononucleosis, and in normal subjects.

Accepted for publication 10 January 1985.

Correspondence to Prof. E J Holborow.

\section{Materials and methods}

SERA

The 205 serum samples tested included 72 from? patients with established rheumatoid arthritis (American Rheumatism Association criteria) attending the Rheumatology Department of the London Hospital, 40 sera giving positive PaulBunnell tests, and 93 sera from healthy adult blood donors. All sera were kept at $-20^{\circ} \mathrm{C}$ until tested $\frac{D}{0}$

MONOCLONAL ANTIBODY A mouse IgG monoclonal antibody made against glial fibrillary acidic protein ${ }^{1}$ and reactive with both? prekeratin and vimentin intermediate filaments of the cytoskeleton was used.

ANTI-INTERMEDIATE FILAMENT ANTIBODY⿱ Anti-intermediate filament antibody was demon strated as previously described. ${ }^{2}$ The human laryngeal carcinoma cell line $\left(\mathrm{HEp}_{2}\right)$ and freshly cultured human fetal skin fibroblasts (HSF) were used as substrate. Cells from stock cultures werę trypsinised and grown as monolayers on multispo slides for $24-72$ hours at $37^{\circ} \mathrm{C}$ in RPMI 1640 mediums 
(Gibco) supplemented with $10 \%$ fetal serum, 300 $\mathrm{mg} / \mathrm{l}$ glutamine and $100 \mathrm{U}$ penicillin and streptomycin in a humidified $5 \% \mathrm{CO}_{2}$ incubator. Twelve hours before their use in tests $0.25 \mathrm{mg} / \mathrm{l}$ of colchicine was added to the cultures. The cell monolayers were fixed in absolute methanol at $-20^{\circ} \mathrm{C}$ for 10 minutes and washed in phosphate-buffered saline, $\mathrm{pH} 7 \cdot 4$. Sera were applied at a dilution of $1: 10$ for 45 minutes at $37^{\circ} \mathrm{C}$, the slides were washed and FITC conjugated sheep antihuman $\mathrm{Ig}$ was then applied at previously determined optimal dilution. FITC conjugated sheep antihuman $\mu, \gamma$ and $\alpha$ chain antisera (Wellcome Reagents Ltd) were used to determine the Ig class of antibodies in positive sera.

\section{ANTIPERINUCLEAR FACTOR ANTIBODY (A P F )}

Preparation of substrate was as reported. ${ }^{3}$ A donor whose buccal mucosal cells gave clearly recognisable staining of keratohyaline granules with APF positive sera was used. The indirect immunofluorescence method as described by Sondag-Tschroots $\mathrm{et} \mathrm{al.}{ }^{4}$ was employed. Sera were applied to the buccal cell smears at a dilution of 1:5 for 90 minutes. The same FITC conjugates were used for fluorescent staining.

\section{ANTIKERATIN ANTIBODY}

Cryostat sections of the middle third of snap-frozen fresh rat oesophagus were used unfixed. The immunofluorescence test was carried out as described by Young et al.$^{5}$ Sera were applied to the sections at a dilution of 1:10 and polyspecific and monospecific FITC conjugates were used as above.

CORRELATION OF THE INCIDENCE OF THE THREE AUTOANTIBODIES

Correlations of the incidences of AIFA, APF, and AKA were sought using the non-parametric Kendal's Tau B test.
IMMUNOFLUORESCENCE MICROSCOPY

Rat oesophagus sections and buccal mucosa cell smears were examined in a Reichert microscope with dark-ground illumination; A 100 W quartzhalogen lamp provided the light source, and Balzer FITC-3 as the primary and Ilford 110 as the secondary filter were incorporated. Cultured cells stained for intermediate filaments were examined on a Zeiss epifluorescence microscope with a $50 \mathrm{~W}$ mercury lamp as the source of illumination.

\section{Results}

\section{ANTI-INTERMEDIATE FILAMENT}

ANTIBODIES

Table 1 shows the prevalence, immunoglobulin classes, and specificities of AIFA in the patient groups and normal subjects, and Fig. 1 the distribution of titres of positive sera. It will be seen that in both RA and IM patients the incidence and titres of AIFA were markedly higher than in normal subjects. The geometric mean AIFA titre in RA was $1 / 40$, in IM $1 / 80$, and in normals $<1 / 10$. In both $R A$ and IM sera AIFA were predominantly of IgM class, and the distribution of specificities for prekeratin and for vimentin were similar in the two conditions. While prekeratin staining was seen only in cultures of $\mathrm{HEp}_{2}$ (epithelial cells), vimentin staining, in accordance with previous reports, was seen in both cultured fibroblasts and colchicine treated $\mathrm{HEp}_{2}$ cells; in the latter in a pattern of perinuclear filament coils, distinct from the spread pattern of prekeratin filaments.

\section{ANTIPERINUCLEAR FACTOR AND}

ANTIKERATIN ANTIBODIES

APF was found predominantly and AKA exclusively in RA sera (Tables 2 and 3 ). In contrast with AIFA, in all positive sera APF and AKA were exclusively of IgG class.

Table 1 Anti-intermediate filament antibodies in normal and patient's sera

\begin{tabular}{|c|c|c|c|c|c|c|}
\hline & \multirow[t]{3}{*}{ No. tested } & \multicolumn{5}{|c|}{ No. $(\%)$ positive for $A I F A$} \\
\hline & & \multirow[t]{2}{*}{ Total } & \multicolumn{3}{|l|}{$\lg M$} & \multirow[t]{2}{*}{$\operatorname{Ig} G$} \\
\hline & & & Prekeratin & Vimentin & $\begin{array}{l}\text { Prekeratin/ } \\
\text { vimentin }\end{array}$ & \\
\hline Rheumatoid arthritis & 72 & $59(82 \%)$ & $22(31 \%)$ & $6(8 \%)$ & $31(43 \%)$ & $4^{*}(5 \%)$ \\
\hline Infectious mononucleosis & 40 & $37(92 \%)$ & $9(22 \%)$ & $4(10 \%)$ & $24(60 \%)$ & $3+(7 \%)$ \\
\hline Blood donors & 93 & $24(26 \%)$ & $4(4 \%)$ & $1(1 \%)$ & $19(20 \%)$ & 0 \\
\hline
\end{tabular}

*One prekeratin, one vimentin, two prekeratin/vimentin.

†One prekeratin, one vimentin, one prekeratin/vimentin.

No sera were positive with anti-IgA conjugate. 


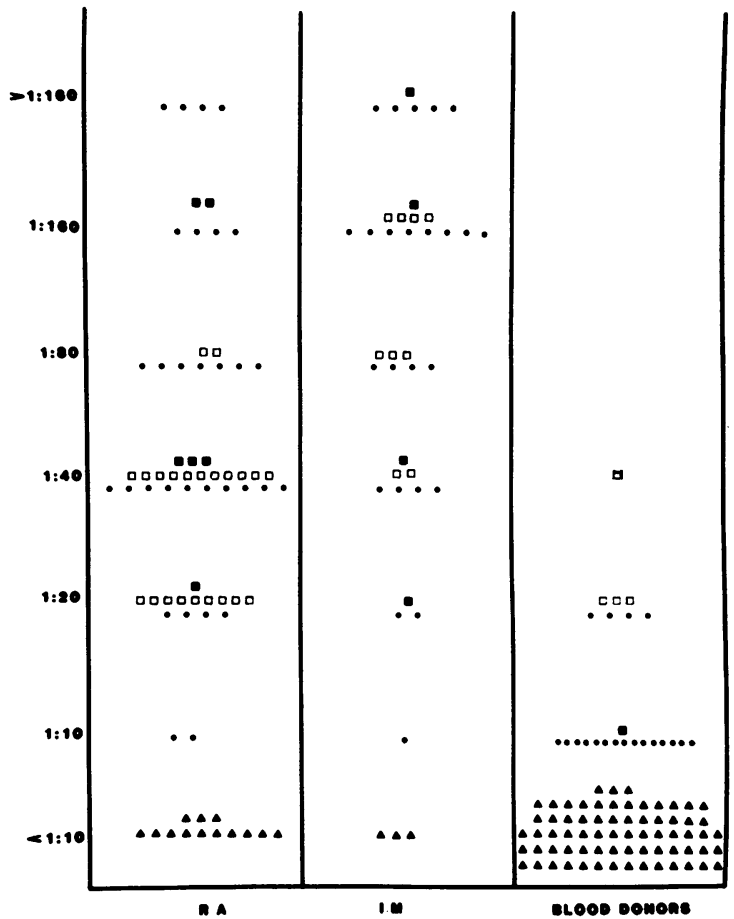

Fig. 1 Titres and specificities of AIFA in RA, IM, and blood donor's sera: $\square$ prekeratin and vimentin staining in colchicine treated $\mathrm{HEp}_{2}$; $\mathrm{O}$ prekeratin staining only in $\mathrm{HEp_{2 }}$ cells; 1 vimentin only (fibroblasts and colchicine treated $\mathrm{HEp}_{2}$ cells); $\Delta$ not positive at a titre of $1 / 10$.

MOUSE MONOCLONAL AIFA

The monoclonal antibody gave staining characteristic of both prekeratin and vimentin intermediate filaments in $\mathrm{HEp}_{2}$ cells and of vimentin in HSF cells. It gave no staining of human buccal mucosal cells or of stratified epithelium in rat oesophagus.

CORRELATIONS BETWEEN POSITIVITY FOR AIFA AND AKA

Table 4 shows that a weak but significant association of AIFA and AKA occurred in RA sera.

Table 2 Antiperinuclear factor antibody

\begin{tabular}{|c|c|c|c|}
\hline & \multirow[t]{2}{*}{ No. tested } & \multicolumn{2}{|c|}{ No. (\%) positive } \\
\hline & & $\lg M$ & $\lg G$ \\
\hline Rheumatoid arthritis & 72 & 0 & $53(73 \cdot 6)$ \\
\hline Infectious mononucleosis & 40 & 0 & $1(2 \cdot 5)$ \\
\hline Normal controls & 93 & 0 & $3 \quad(3 \cdot 2)$ \\
\hline
\end{tabular}

Table 3 Antikeratin antibody

\begin{tabular}{|c|c|c|c|}
\hline & \multirow[t]{2}{*}{ No. tested } & \multicolumn{2}{|c|}{ No. (\%) positive } \\
\hline & & $\operatorname{Ig} M$ & $\operatorname{Ig} G$ \\
\hline Rheumatoid arthritis & 72 & 0 & $39(54 \cdot 2)$ \\
\hline Infectious mononucleosis & 40 & 0 & 0 \\
\hline Normal controls & 93 & 0 & 0 \\
\hline
\end{tabular}

Table 4 Correlations between positive tests for AIFA, $A P F$, and $A K A$ antibodies in $R A$

Correlations*

\begin{tabular}{lll}
\hline AIFA and APF & AIFA and AKA & APF and AKAF \\
\hline$p=0.0381 \ddagger$ & $\mathrm{p}=0.1382 \dagger$ & $\mathrm{p}=0.0860 \dagger$
\end{tabular}

*Kendal's Tau B test.

†Not significant.

$\ddagger$ Significant.

\section{Discussion}

These findings confirm that the AIFA, AKA, and APF shown in the sera tested are antibodies of different specificities. The failure of the mouse monoclonal anti-AIFA to react with keratohyalinen granules or with rat oesophageal epithelium, $\mathbb{D}$ although reacting strongly with $\mathrm{HEp}_{2}$ cells and fetal fibroblasts, accords with this.

The prevalence and isotypes of these three antibodies in the RA and normal sera examined here agree with previous reports. ${ }^{2} 31819$ This study also brings out strikingly, however, the matching high incidence of IgM AIFA in RA and in IM, in:both conditions at titres very significantly higher than in normals. In contrast, though AKA and APFo were present in a clear majority of the RA seratested, APF was present in only a small percentageo of IM sera, and AKA was never found.

A high incidence of AIFA in IM was reported byo Linder et al. ${ }^{6}$ and Mortazavi-Milani, ${ }^{7}$ and we have confirmed elsewhere the high incidence of AIFA ino Paul-Bunnell positive glandular fever. ${ }^{8}$ AIFA is one of a number of autoantibodies occurring in acute infectious mononucleosis, and it is possible thatthese appear at least partly as a result of the polyclonal activation of B lymphocytes by EpsteinBarr virus (EBV). We have described elsewhere thes? induction of IgM AIFA in lymphocyte cultures infected with $\mathrm{EBV}^{9}$ or stimulated with supernatantso from Plasmodium falciparum cultures, ${ }^{10}$ and also 0 the occurrence of AIFA in sera from other infec-त्D tious conditions (malaria, trypanosomiasis, ${ }^{11}{ }^{12}$ ) in which the infecting organisms likewise exert a 
polyclonal mitogenic effect on the host's lymphocytes and especially on IgM production. ${ }^{13}$ It appears reasonable to surmise that similar action of an unknown polyclonal mitogen may underlie autoantibody production in RA.

Pursuit of the EBV analogy leads to a second possibility. EBV, gaining entry to the body as it supposedly does by initially infecting epithelial cells in the throat, may in the process in some way enhance the immunogenicity of prekeratin intermediate filaments in the cytoskeleton of the implicated epithelial cells. As we have shown here the AIFA activity in both RA and IM sera may be specific for prekeratin in $\mathrm{HEp}_{2}$ cells or for vimentin in fibroblasts and colchicine treated $\mathrm{HEp}_{2}$ cells; or sera may show both patterns of reactivity. Experiments reported by Mortazavi-Milani ${ }^{7}$ indicated that in at least some RA sera dual AIFA specificity reflects the presence of two antibodies of different specificities. It cannot be excluded, however, that some IgM AIFA in patients may, like the monoclonal mouse antibody described here, react with epitopes common to the two intermediate filament proteins. The two other autoantibodies that we have included in this study, APF and AKA, are indisputably directed at antigens exclusively present in epithelial cells. It thus seems possible that in RA an infectious agent with an epithelial portal of entry confers enhanced immunogenicity on certain components of implicated epithelial cells, and that this in turn leads to production of the triad of autoantibodies AIFA, APF, and AKA. It is not clear, it must be admitted, how such a hypothesis might explain either the presence of solely antivimentin specific AIFA in a minority of patients' sera, or the Ig isotype differences we have found between the three antibodies of the triad present in RA sera.

A number of other autoantibodies that are associated with different clinical subsets of connective tissue diseases have recently been shown to be directed at different members of a range of complex cytoplasmic and nuclear antigens of varied nucleic acid-protein composition. It has been postulated that these complex molecules display enhanced autoimmunogenicity because they include a molecular contribution of viral origin. ${ }^{14-16}$ It has moreover been reported that some viruses need intermediate filaments for their intracellular replication. ${ }^{17}$ The possible role of viral components or products in enhancing the autoimmunogenicity of cytoskeletal proteins in diseases such as RA seems to merit further investigation.

We thank Dr D Bainbridge, London Hospital Clinical Immunology Laboratory for the sera giving positive Paul-Bunnell tests, the North East London Blood Transfusion Service for the sera from blood donors. Dr B H Anderton, Immunology Department, St Georges Hospital Medical School, London for the mouse IgG monoclonal antibody, and Dr J Holmes, Hill Centre, The London Hospital Medical College for carrying out the Kendal Tau B test.

\section{References}

1 Pruss R M, Miraky R, Raff M C. Thrope R, Dowling A J, Anderton B H. All classes of intermediate filaments share a common antigenic determinant defined by a common antibody. Cell 1981: 27: 419-28.

2 Osung O A, Chaudra M, Holborow E J. Antibodies to intermediate filaments of the cytoskeleton in rheumatoid arthritis. Ann Rheum Dis 1982; 41: 69-73.

3 Johnson G D, Carvalho A, Holborow E J, Goddard D H, Russell G. Antiperinuclear factor and antiprekeratin antibodies in rheumatoid arthritis. Ann Rheum Dis 1981; 40: 263-6.

4 Sondag-Tschroots I R J M. Aaij G. Smith J W, Feltkamp T E W. The antiperinuclear factor: the diagnostic significance of the antiperinuclear factor for rheumatoid arthritis. Ann Rheum Dis 1979; 38: 248-51.

5 Young B J J, Mally R K, Leslie R D G, Clark C J M, Hamblin $\mathrm{T} \mathrm{J}$. Antikeratin antibodies in rheumatoid arthritis. $\mathrm{Br}$ Med $\mathrm{J}$ 1979: ii: $97-9$.

6 Linder E, Kurki P, Andersson L C. Auto-antibody to intermediate filaments' in infectious mononucleosis. Clin Immunol Immunopathol 1979; 14: 411-41.

7 Mortazavi-Milani S M. An immunological study of intermediate filament of the cytoskeleton. University of London, 1982. 83 pp. (PhD thesis.)

8 Kataaha P K. Holborow E J, Edwards J M B. The incidence of anti-intermediate filament antibody in sera of students with suspected glandular fever. J Clin Pathol 1985; 38: 351-4.

9 Mortazavi-Milani S M, Stierle H E, Holborow E J. In vitro induction of anti-intermediate filament antibody in lymphocyte cultures by Epstein Barr virus. Immunol Lett 1982; 5: 203-5.

10 Kataaha P K, Facer C A, Mortazavi-Milani S M, Stierle H, Holborow E J. Stimulation of auto-antibody production in normal blood lymphocytes by malaria culture supernatants. Parasite Immunol 1984; 6: 481-92.

11 Mortazavi-Milani S M, Badakere S S, Holborow E J. Antibody to intermediate filaments of the cytoskeleton in the sera of patients with acute malaria. Clin Exp Immunol 1984; 55: 177-82

12 Mortazavi-Milani S M, Facer C A. Holborow E J. Induction of anti-intermediate filament antibody in rabbits experimentally infected with Trypanosoma brucei brucei. Immunology 1984; 52: 423-6.

13 Abele D C, Tobie J E, Hill G J, Conta Co S P J, Evans C B. Alterations in serum proteins and $19 \mathrm{~S}$ antibody production during the course of induced malarial infection in man. $A m J$ Trop Med Hyg 1965; 14: 91.

14 Matthews M B, Rerstein R M. Myositis auto-antibody inhibits histidyl tRNA synthesis: a model of auto-immunity. Nature 1983; 304: 177-9.

15 Polz P H. Viruses and auto-antibodies: auto-antibodies are antiidiotype antibodies to anti-viral antibodies. Lancet 1983; ii: $824-6$.

16 Anonymous. The viral actiology of rheumatoid arthritis [Editorial]. Lancet 1984; i: 772-4.

17 Cervera M. Dreyfuss G. Penman S. Messenger RNA is translated when associated with the cytoskeletal framework in normal and VSV infected Hela cells. Cell 1981; 23: 113-20.

18 Kurki P, Helve T, Virtanen I. Antibodies to cytoplasmic intermediate filaments in rheumatic diseases. $J$ Rheumatol 1983; 10: 558 .

19 Quismorio F P, Kaufman R L, Beardmore T, Morgan E. Reactivity of serum antibodies to the keratin layer of rat oesophageal in patients with rheumatoid arthritis. Arthritis Rheum 1983; 26: 494. 